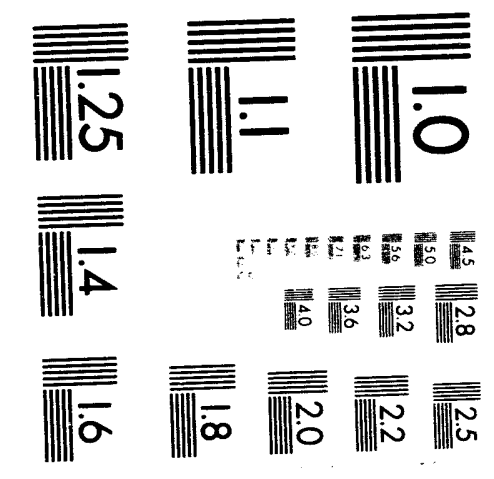



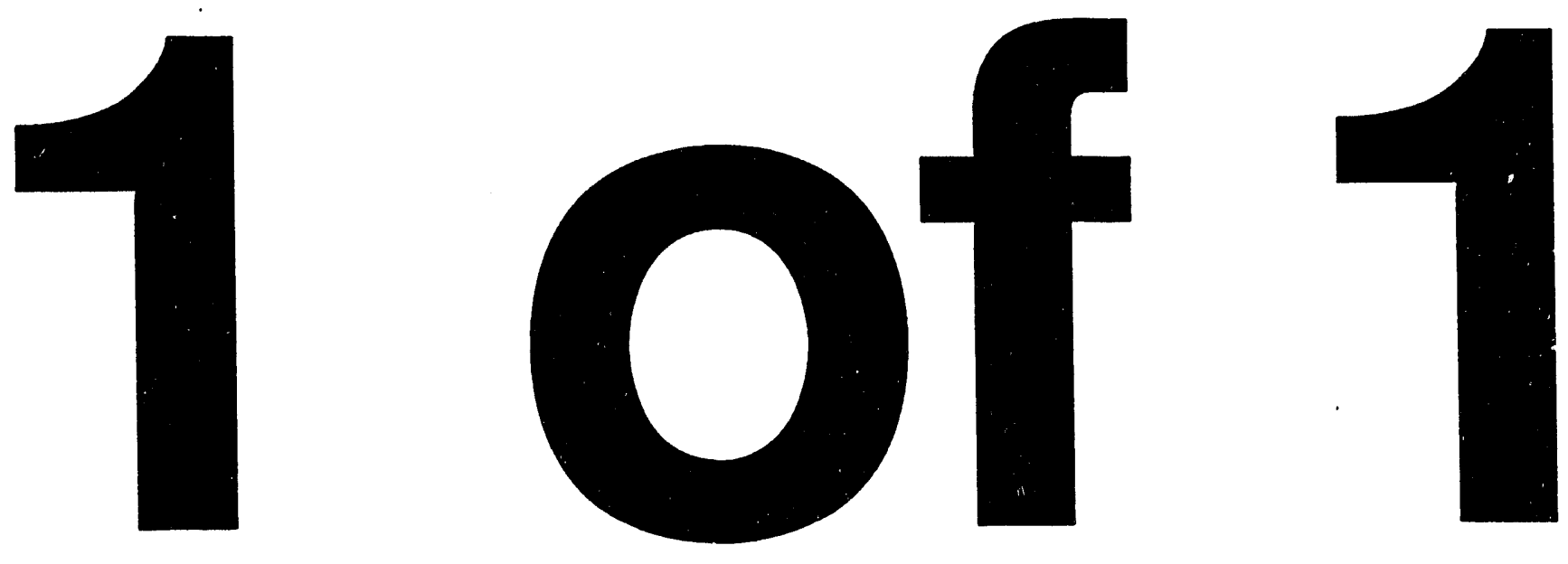


\section{TASK TECHNICAL PLAN: DWPF AIR PERMIT/DISPERSION MODELING (U)}

by

D.P. Lambert

Westinghouse Savannah River Company

Savannah River Site

Aiken, South Carolina 29808

This paper was prepared in connection with work done under the above contract number with the $U$. S.

Department of Energy. By acceptance of this paper, the publisher and/or recipient acknowledges the U. S. Government's right to retain a nonexclusive, royalty-free license in and to any copyright covering this paper, along with the right to reproduce and to authorize others to reproduce all or part of the copyrighted paper. 


\section{DISCLAIMER}

This report was prepared as an account of work sponsored by an agency of the United States Government. Neither the United States Government nor any agency thereof, nor any of their employees, makes any warranty, express or implied, or assumes any legal liability or responsibility for the accuracy, completeness, or usefulness of any information, apparatus, product, or process disclosed, or represents that its use would not infringe privately owned rights. Reference herein to any specific commercial product, process, or service by trade name, trademark, manufacturer, or otherwise does not necessarily constitute or imply its endorsement, recommendation, or favoring by the United States Government or any agency thereof. The views and opinions of authors expressed herein do not necessarily state or reflect those of the United States Government or any agency thereof.

This report has been reproduced directly from the best available copy.

Available to DOE and DOE contractors from the Office of Scientific and Technical Information, P. O. Box 62, Oak Ridge, TN 37831; prices available from (615) $576-8401$.

Available to the public from the National Technical Information Service, U. S. Department of Commerce, 5285 Port Royal Rd., Springfield, VA 22161 
Keywords: DWPF, Air Emissions, Air Dispersion Modeling, Benzene, Mercury, Nitrogen dioxide, Late Wash

Retention Period: Permanent

cc: $\quad$ M. N. Brosee, 704-S

A. G. Peterson, 704-S

J. W. Wilson, 210-S

S. C. Piccolo, 704-S

W. T. Davis, 210-S

J. A. Gentilucci, 704-S

J. F. Ortaldo, 704-S

M. J. Montini, 704-S

W. T. Goldston, 704-S

W. D. Kerley, 704-33S

J. T. Carter, 704-25S

K. C. Wolf, 704-15S

R. D. Reeves, $704-15 \mathrm{~S}$

S. R. Wilson, 704-S

W. J. Vetsch, 704-S

November 8, 1993

D. B. AMERINE, MANAGER, DWPF

WESTINGHOUSE SAVANNAH RIVER COMPANY

ATTENTION: W. D. KIMBALL, 704-S (5)

\section{Task Technical Plan \\ DWPF Air Permit/Dispersion Modeling (U)}

This Task Technical Plan summarizes work required to project the benzene emissions from the Late Wash Facility (LWF) as well as update the benzene, mercury, and $\mathrm{NO}_{\mathbf{x}}$ emissions from the remainder of DWPF. These calculations will reflect (1) the addition of the LWF and (2) the replacement of formic acid with nitric acid in the melter preparation process. The completed calculations will be used to assist DWPF in applying for the LWF Air Quality Permit.

Any questions you may have should be referred to L. F. Landon (5-6403) or D. P. Lambert (5-6380).

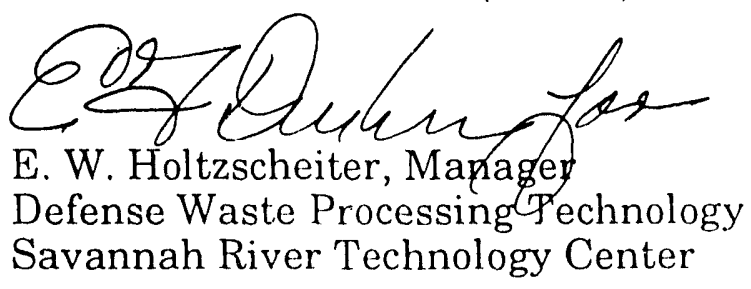


Keywords: DWPF, Air Emissions, Air Dispersion Modeling

cc: L. M. Papouchado, 773-A

A. L. Boni, 773-A

E. W. Holtzscheiter, 773-A

J. A. Gentilucci, 704-S

E. F. Duhn, 773-A

R. P. Addis, 773-A

M. J. Plodinec, 773-A

D. A. Crowley, 704-T

C. T. Randall, 704-T

N. H. Kuehn, 704-T

S. A. Budenstein, 704-1T

T. K. Snyder, 704-T

J. Stewart, 773-A

Air Permit QA File

PTD Group (9)

LSE Group (12)

TIM, 703-43A, Rm 26 (4)

Retention: Permanent

To: $\quad$ L. F. Landon, 704-1T

November 8, 1993

From: D. P. Lambert, 704-1T ben falut

\section{Task Technical Plan DWPF Air Permit / Dispersion Modeling (U)}

Task Technical Requests (TTRs)

J. A. Gentilucci, Dispersion Modeling for DWPF Air Permit (U), OPS-DTF930102, October 13, 1993.

J. A. Gentilucci, Dispersion Modeling for Auxiliary Pump Pit Air Permit (U), OPS-DTF-930100, October 13, 1993.

\section{INTRODUCTION}

This Task Technical Plan outlines the activities to be conducted in calculating benzene, $\mathrm{NO}_{\mathrm{x}}$, and mercury releases from the Defense Waste Processing Facility (DWPF) and the Auxiliary Pump Pit (APP). These data will be used for dispersion modeling of ernissions from the APP and DWPF. A summary report will be submitted to DWPF to assist t'nem in applying for the Late Wash Facility (LWF) Construction Air Quality Permit.
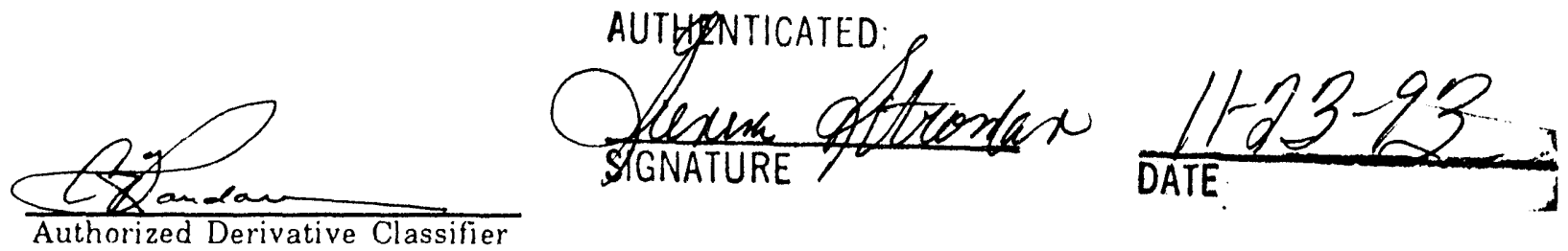


\section{Program Objectives}

Supply DWPF with projected annual and maximum instantaneous benzene, $\mathrm{NO}_{\mathrm{X}}$, and mercury emissions from the LWF and DWPF. Also, complete air dispersion modeling of projected emissions from the APP and DWPF.

\section{Tasks Required to Meet Program Objectives}

DWPT will complete calculations of annual and maximum instantaneous benzene, $\mathrm{NO}_{\mathrm{X}}$, and mercury emissions from the LWF and DWPF. These are Level 1

Calculations as defined by procedure 2.31 of the E7 manual. 1 The technical accuracy of the calculation will be verified by an independent engineer.

Environmental Transport will complete air dispersion modeling of projected emissions from the APP and DWPF using EPA approved computer models (Industrial Source Complex Short Term Model, Release 2).

\section{Discussion}

The DWPF emissions were previously estimated using the HAN flowsheet in the Salt Process Cell and the formic acid flowsheet in the Chemical Process Cell. ${ }^{2}$ Previous calculations by SRTC were used to develop the current air permit requirements. ${ }^{3}$ The DWPF process has been modified to utilize the late wash flowsheet in the Salt Process Cell and the nitric acid flowsheet in the Chemical Process Cell. As a result of these process changes, benzene emissions are being recalculated to support the development of a construction Air Quality Permit for the Late Wash Facility.

\section{Customer}

DWPF Process Engineering is the customer for this task. The Manager of SRTC Defense Waste Processing Technology (DWPT) is responsible for acting as DWPF's agent in providing guidance and oversight for the customer during the performance of the emission calculations. The Manager of SRTC Environmental Transport is responsible for acting as DWPF's agent in providing guidance and oversight for the customer during the performance of the air dispersion modeling.

\section{TASK DESCRIPTION}

\section{Task Deliverables}

Task deliverables are the technical reports which document the outcome of this task. The calculations will be summarized in a report that will be transmitted to the DWPF Manager, Attention: DWPF Engineering Director.

Other planned deliverables are listed as follows:

- LWF annual and maximum instantaneous benzene release calculation.

- DWPF annual and maximum instantaneous benzene release calculation.

- DWPF annual and maximum instantaneous $\mathrm{NO}_{\mathrm{X}}$ release calculation. 
- DWPF annual and maximum instantaneous mercury release calculation.

- Dispersion modeling for the APP and DWPF.

\section{Task Requirements}

DWPF requested calculation of benzene, $\mathrm{NO}_{\mathrm{x}}$, and mercury emissions. DWPF also requested the completion of air dispersion modeling for $\mathrm{DWPF}^{4}$ and the Auxiliary Pump Pit ${ }^{5}$. The emissions calculations will be completed by DWPT and the dispersion modeling will be completed by Environmental Transport.

The TTRs require air dispersion modeling which will modify the DWPF Technical Baseline. As a result, all calculations will be performed using the review required by the Conduct of Engineering and Technical Support Procedure Manual Procedure $2.31 .{ }^{6}$ The TTRs also request a Task Specific QA Plan, referencing SC DHEC approved calculational methods. SC DHEC has promulgated standards for emissions of benzene and mercury under Regulation 62.5, Standard No. 8 (24 hour averaging) and a standard for $\mathrm{NO}_{\mathrm{x}}$ emissions under Regulation 62.5, Standard No. 2 (annual averaging)

Other requirements for this task are listed below:

- All DWPT activities associated with this task are to be performed according to the DWP\&HT QA Implementing Procedure 2-3 of 1 Q43. ${ }^{7}$ A task plan is to be prepared and must be approved by the DWPT manager.

- All Environmental Transport activities associated with this task are to be performed according to the approved Task Technical and Quality Assurance Plan. ${ }^{8}$

- Any change in task objectives requires a revision or addendum to this Task Plan be prepared and approved per DWP\&HT QA Implementing Procedure 2-3 of 1Q43.9

- A records package is to be developed for this effort. This package must be sufficiently complete so that the calculations could be independently performed in order to reconstruct the results, if necessary.

\section{Task Prerequisites}

All emission calculations must be completed and verified before the dispersion modeling can be completed.

\section{Task Activities Requiring Control}

A Task QA Plan will be prepared (as required by DWP\&HT QA implementing procedure 2-3 of QA Manual 1Q43) which identifies the QA controls for this task. The Environmental Transport QA plan has been approved. ${ }^{10}$ 
- The calculations will be summarized in a report that will be transmitted to the DWPF Manager, Attention: DWPF Engineering Director.

- LWF annual and maximum instantaneous benzene release calculation.

- DWPF annual and maximum instantaneous benzene release calculation.

- DWPF annual and maximum instantaneous $\mathrm{NO}_{\mathrm{x}}$ release calculation.

- DWPF annual and maximum instantaneous mercury release calculation.

- Dispersion modeling for the APP and DWPF.

\section{RECORDS}

\section{Task QA File}

A QA file will be established for the jerformance of this task. This QA file will become the records package at the completion of this task and will document pertinent information produced during the performance of this task. The establishment of this QA file and the control of this file will be documented separately.

The records package generated from this QA file will contain (at a minimum) the following documents:

- $\quad$ Task Technical Plan, WSRC-RP-93-1447

- Task QA Plan

- $\quad$ Copies of task technical reports.

- Copies of the engineering calculations for each calculation performed.

- An index of the contents of the records package.

\section{Task Technical Reports}

The technical reports to be generated as a result of this task are listed in the Task Deliverables section. These reports are the outcome of this task.

\section{SCHEDULE}

The completion of this task has been requested by October 20,1993. Because of the requirements involved in managing this task, the final completion is not expected before November 22, 1993. 


\section{APPROVAL}

MANAGEMENT APPROVAL

$\frac{\text { Savid a. Gowley }}{\text { D. A. Crowley }} \frac{10 / 28 / 93}{\text { Date }}$ Manager, DWPT Large Scale Experimentation Group

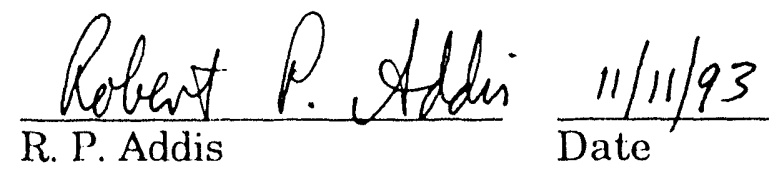
Manager, Environmental Technology Group

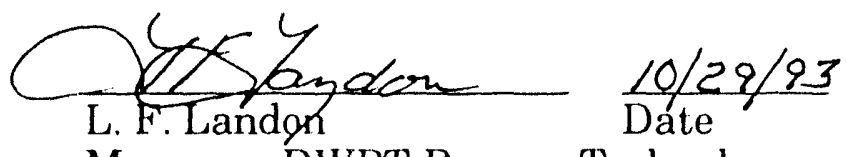

Manager, DWPT Process Technology

Development Group

\section{CUSTOMER CONCURRENCE}

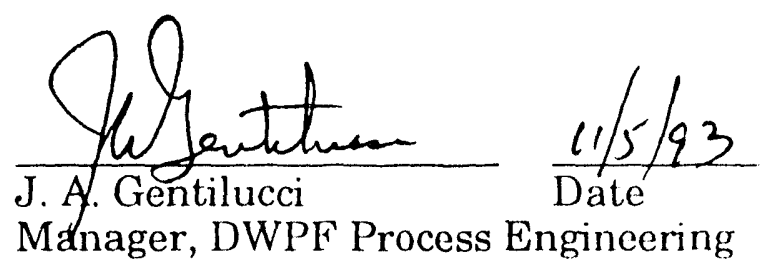

\section{QTHER CONCURRENCES}

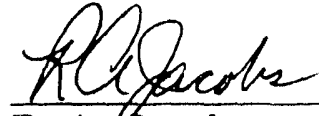

R. A.Tacobs

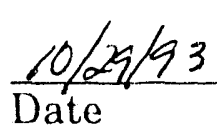

$\frac{\text { Paul R. Gronson }}{\text { P.R. Monson }} \frac{10 / 29 / 93}{\text { Date }}$

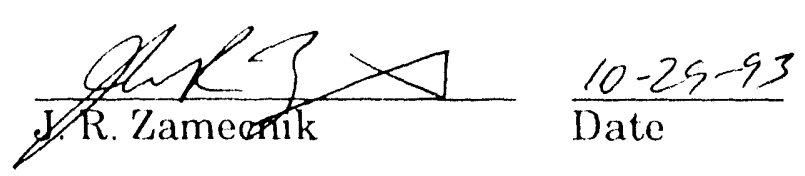

EWtaltzathes

E. W. Hollzscheiter Manager DWPT
$10 \cdot 29-93$ Date 


\section{E. References}

1 E7 Manual, Procedure 2.31, Engineering Calculations (U), Revision 0, September 30, 1993.

2. ESH-ESF-93-0509, C. M. Cook, Revised Operating Permit for S-Area, September 14, 1993.

3. R. A. Jacobs, DWPF Benzene Emissions, WSRC-RP-90-0536, May 29, 1990.

4 J. A. Gentilucci, Dispersion Modeling for DWPF Air Permit (U), OPS-DTF930102 , October 13, 1993.

5 J. A. Gentilucci, Dispersion Modeling for Auxiliary Pump Pit Air Permit (U), OPS-DTF-930100, October 13, 1993.

6 E7 Manual, Procedure 2.31, Engineering Calculations (U), Revision 0, September 30, 1993.

7. DWPT\&HT Quality Assurance Procedures Manual, DWP\&HT Department QA Implementing Procedure 2-3, "Control of Research and Development Activities", Revision 0, May 10, 1991.

8 WSRC-RP-93-704, Task Technical and Quality Assurance Plan for SRS Atmospheric Emissions Inventory (AEI Air Quality Modeling)(U), May 12, 1993.

9. DWPT\&HT Quality Assurance Procedures Manual, DWP\&HT Department QA Implementing Procedure 2-3, "Control of Research and Development Activities", Revision 0, May 10, 1991.

10 WSRC-RP-93-704, Task Technical and Quality Assurance Plan for SRS Atmuspheric Emissions Inventory (AEI Air Quality Modeling)(U), May 12, 1993. 

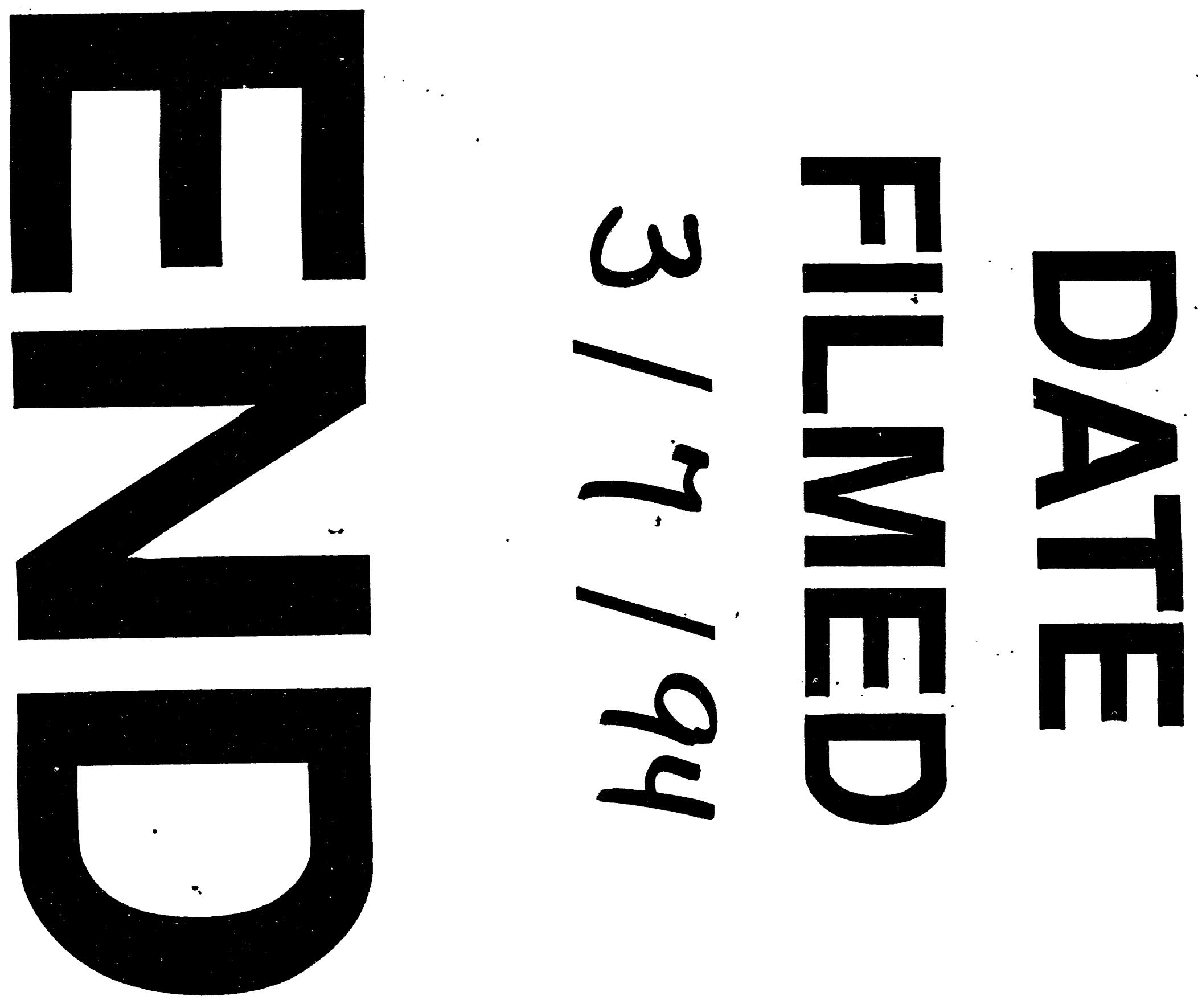
